\title{
Saints, Demons, Wizards, Pagans, and Prophets in the Collapse of Banks in Ghana
}

\section{Cletus Agyenim- Boateng}

Department of Accounting University of Ghana Business School

\section{Francis Aboagye- Otchere}

Department of Accounting University of Ghana Business School

\section{Alice Anima Aboagye}

Department of Accounting University of Ghana Business School

\section{Correspondence:} cagyenim-boateng@ug.edu.gh faotchere@ug.edu.gh aaaboagye002@st.ug.edu.gh

P. O. Box LG 78, Legon, Accra, Ghana

https://dx.doi.org/10.4314/ajmr. v27i1.2

\begin{abstract}
The essence of banks in an economy cannot be underscored enough. However, poor institutional as well as unscrupulous banking and accounting practices could collapse a banking system and wreak an economy-wide havoc due to a contagion. Thus, the impact of bank failures/crises are grave. Given that this paper seeks to comprehensively discuss bank failures in the light of both agency and structural perspectives. Also, the study theorizes the causes of bank failures using Ayee's (2000) concepts and Pierre Bourdieu's theory of social practice. The study adopted a qualitative methodology and used nine failed Ghanaian banks as cases. A latent content analysis on reports of these recent nine failed banks indicated the banking crises were a reproduction of old social actions, which include weak regulatory supervision, poor corporate gover-nance and risk management practices. Besides, the culture of weak enforcement explained the collapse of the local banks unlike their foreign counterparts who had internalized the culture of their parent companies and also possessed the right cultural capitals. Further, it was observed that weak saints, hungry and deceitful demons, lazy wizards, praise and attention-loving pagans and the neglect of prophets were the issues responsible for the bank crises or failures in Ghana.
\end{abstract}

Keywords: bank failures, bank crises, saints, demons, prophets, corporate governance

\section{Introduction}

Banks are key constituents of the financial sector and instrumental in every nation's socio-economic development (Sikka, 2009; PricewaterhouseCoopers and Association of Bankers, 2016; ILO, 2019). In modern 
times, globalization and digitalization have extended the frontiers of banking. These trends have facilitated the ability to establish/own banks outside one's geographical location. Thus, financial globalization enhances foreign bank's participation and presence in developing countries (Cull and Soledad Martinez Peria, 2010). As a result, subsidiary banks are enabled to access funding through their parent companies in the international markets.

Although these trends have sparked up innovation in the banking sector and a transfer of intellectual and economic capital, it has not been devoid of problems. Carbo-Valverde (2017) explains that digitalization poses new risks for regulators and supervisors, since it can create financial fragility because of the huge amount of intangible capital associated with it. Similarly, Ghosh (2016) indicates that financial globalization reduces earnings which is a precursor to bank failures.

Banking crisis is a situation in which there is substantial indication of bank distress; which is characterized by many bank runs, bank collapses, and bank losses or significant policy intervention measures focused on banks (Laeven \& Valencia, 2010). Bank crisis is a global phenomenon since virtually every country in the world has experienced some form of bank failure or bank crisis (Laeven \& Valencia, 2013; Honohan \& Klingebiel, 2003). Furthermore, both developed and developing economies have not escaped the clutching hands of bank failures. For instance, Canada, UK, USA, Sweden, Japan as well as Ghana have had bank failures. However, the Ghanaian banking sector has witnessed the collapse of nine local banks over a two-year period spanning
2017 and 2019. These failures are worth examining hence the essence of this study.

\section{Problem Statement}

The banking industry dominates the Ghanaian financial sector and has been instrumental in Ghana's development. Specifically, the assets of banks are about $85 \%$ of the financial sector's assets (Bank of Ghana, 2018). Thus, the importance of banks to societies and the economy cannot be underrated. (Arif \& Nauman, 2012). That notwithstanding, banks are predisposed to high levels of risk (Lindé \& Wallgren, 2012) that could result in bank failures/crises when not properly managed. Ghana hasn't been spared of these crises. Precisely, Ghana has had about five major bank crises over the past five decades with most of the failed banks being local banks (see Antwi-Asare \& Addison, 2000). This leaves us with the question of what could be accounting for the failure of these local banks?

Further, studies indicate that bank crisis is complex and difficult to reliably forecast (Falasca, 2014; Čihák \& Schaeck, 2010). Also, bank crisis could be inimitable despite its pervasiveness. Thus, bank crisis reflects the banking structure specifically the banking regulations of the context of occurrence.

As a result, the debates on bank crisis and its resolution have largely been centered on regulations (DeYoung \& Torna, 2013; Lietaer, Ulanowicz \& Goerner, 2009). These authors argue that the structures should be critically observed in addressing bank crisis. However, it has been established that banking crises also entail numerous actors (Falasca, 2014).

Specifically, operational risk: which is one 
of the key bank risks (Vyas \& Singh, 2011), has an element of agency. Hence, it would be inappropriate to neglect the actors involved in bank crisis since bank practices are outcomes of the interactions between the actors and institutional logics (rules). Despite this, only a few studies have considered the role of actors in the banking crises (see Hill, 2009; Neate, 2012).

Additionally, bank crisis has grave economic and social implications. The collapse of these financial institutions (banks) saddles both the populace and the ruling government with a huge cost. Economically, bank failures and their bailouts are expensive to taxpayers (Minford, 2010). This is because the government spends large sums of the tax revenue to safeguard or recover the mess created by these institutions. Specifically, the Bank of Ghana (BoG) spent a total amount of about 14 billion Cedis, which accounts for about $3.5 \%$ of Gross Domestic Product in cleaning up the sector after the recent Ghanaian banking crisis (Dzawu, 2019; PricewaterhouseCoopers and Association of Bankers, 2019. Also, bank crisis causes unemployment (Laeven, 2011) hence stifling economic growth. Further, investors in those failed institutions tend to lose their investments which deters others from investing in the economy. Besides this could reduce the confidence of citizens in the banking system, which is considered to be under-subscribed (PricewaterhouseCoopers and Association of Bankers, 2016). Accordingly, these failures tend to have negative ripple effects on the sectors of the economy and could cause a recession.

Hence, this study seeks to gain answers to the following questions. Is the crisis new or just a reproduction of social actions? Could the structure of Ghana's banking explain the bank failures? It would also theorize the failure of the banking regulations; by specifically focusing on the actors involved in the bank crisis, by extending Ayee's (2000) conceptualization of why policies fail or succeed.

\section{Literature Review \\ Causes of Banking Crisis}

The economic and social implications: such as unemployment, loss of investments and others, of bank crisis makes it important to scrutinize the issues that cause it. Lietaer et al. (2009, p.1) state that bank crisis may not necessarily be due to managerial failure but also due to varying regulatory systems. Broadly, the factors that account for bank crises can be categorized into two; internal and external shocks. However, the explanatory variables for bank crisis could be context driven.

Generally, weakness in accounting, auditing and disclosure, poor risk management, non-performing loans, illiquidity and poor lending practices could cause bank crisis (Diamond \& Rajan, 2005; Sikka et al., 2009; Sanoran, 2018). Fraudulent activities, poor bank corporate governance (CG) mechanisms as well as poor knowledge and experience of bank directors on risk and bank management can result in bank failures (Laeven \& Levine, 2009; Guerrera \& Thal-Larsen, 2008; Bernburg, 2016). Further, government involvement or political interference accounts for bank crisis (Brown \& Dinç, 2005; IMF, 2011).

According to Dimurgüç-Kunt and 
Detragiache (1998), the banking structure of a country could cause a crisis. Increased regulation as well as failure of regulatory oversight could result in bank failures (Magnan \& Markarian, 2011; Calomiris, 2008). Specifically, Calomiris (2008) indicates that increased safety mechanisms of the banking sector could trigger the risk of bank failures. Again, Garcia and Nieto (2005) assert that weak supervision and lack of clearly laid down rules account for bank crisis. Thus, the lack of comprehension on some rules by supervisors causes poor diligence in their governance practices (Muranda, 2006). It is also perceived that the global crisis of other jurisdictions could lead to bank failures (IMF, 2011). Laeven (2011) also found bank runs and bank contagion to explain crisis. Excessive inflation and devaluation have been known to both account for bank failures as well (Antwi-Asare \& Addison, 2000; Laeven, 2011). Further, it's been observed that national culture could influence bank performance negatively hence its failure (cf. Boubakri, Mirzaei \& Samet, 2017). Thus, the framing of bank crisis considers both the regulations and values and practices of its actors.

\section{Theoretical Underpinnings}

The researchers sought to apply concepts from Ayee (2000) and Bourdieu (1977) theory of social practice to explain the banking crisis in Ghana.

\section{Concepts from Ayee (2000)}

Bank crisis, like other crisis, is a key concern for policymakers (Boubakri et al., 2017) and may contribute to the varied regulations after a crisis. Thus, whenever there are crises amidst regulation it connotes that the policy in place has failed to achieve its purpose. According to
Hernando et al. (2018), since most people are beginning to devalue the efficacy of banking policies, it is expedient to observe what causes those policies to be ineffective. Therefore, the study uses Ayee's conceptualization of why policies fail to achieve their intended purposes to explain the role of the actors involved in the bank crisis. Ayee (2000, p.1) answers the question by stating that policies fail because saints are few, wizards are inappropriate, demons are many, the systems are complex and the organizations are weak.

Ayee (2000, p.14) explains that Saints are committed politicians and bureaucrats who formulate and follow through with the implementation of a policy even if it makes them disliked by the populace. These actors tend to be well connected politically and have the necessary resources; skills for handling employees and other actors, for successful implementation of policy. Thus, Saints are required for every successful banking policy.

Wizards are perceived to be destroyers. However, Ayee (2000, p.26) conceptualization connotes smart and critical actors who could enhance the success of policies. Therefore, he categorizes appropriate policy analysts as wizards because they can aid the saints by providing available and reliable information that could modify waning firms into effective firms. They are characterised by describing and seeking explanations to policies as well as testing them through research to provide evidence for policy reviews. Consequently, failure of wizards to perform their roles would amount to policy failures and crises.

Demons have negative connotations and do 
not want successful policies. Ayee (2000, p.45) refers to these actors as corrupt public officials who should be eliminated if policies are to succeed. Further Ayee (2000, p.44) asserted that demons may not necessarily be corrupt officials but also individuals who perceive a policy may threaten their power, position and competence. He added that anyone who acts negatively toward new policies because their implementation would enhance the reputation of his/her partners other than $\mathrm{him} /$ herself is characterized as a demon. Issues of ethics or values of actors come to bear since actors in the banking field with bad values are likely to cause bank collapse.

Further systems are believed to be a set of interrelated activities put together to achieve a goal. Hence, Ayee (2000, p.46) argues that policy success/failure must be considered within its political and social context. He further states that the system normally focuses on formulation without considering how it will be enforced. The enforcement mechanisms are thought of, after the formulation. Also, he asserted the need for policymakers to desist from making policies a private activity with just a few elites (2000, p.47) and encourage broader participation.

Ayee (2000) concepts are useful in this study because Ghana has made several reforms in the banking sector yet have had some crises over the period especially shortly after the immediate enactment of Act 930. This theory provides a lens for examining the actors involved the bank failures despite the reforms.

\section{Bourdieu Theory of Social Practice}

This theory propounded by Pierre
Bourdieu examines processes and actors in a situation and how change could be made (Becker \& Horowitz, 1972). It is primarily concerned with reconciling firm structures and processes and actors.

The theory has three elements namely field, capital and habitus. According to Bourdieu, a field is a system of positions and interactions among positions (Costa, 2006). Thus, it is the space which provides room for the dialectic interaction between actors and structures. The field has its rules of engagement known as field logics. Also, the position of an actor in a field is determined by his/her capital. Capital is the resources an actor has in his/her possession, which enables him/her to participate in a field (Caine, 2013). The number of capital and the kind of capital an actor possesses could change his/her position or status in a field (Bourdieu, 1986). Further, Habitus is the dispositions; values, preferences etc. of an actor (Caine, 2013). Habitus is an embodiment of societal values and some past experiences. Bourdieu (1977) claims that habitus also entails the taken-for-granted (Doxa) nature of society which is learned by the actor (Bourdieu, 1977). Habitus is perceived to be durable or lasting especially when the conditions are similar to those under which it was made (Costa, 2006). However, they can be unlearned (Caine, 2013).

These three concepts are interlinked. An interaction of the three concepts results in what is called practice. According to Costa (2006, p.875), social practices are determined by the relationships between interests and positions. However, Bourdieu discussed the com-prehension of a social actor's practices is embedded in the con- 
cept of habitus. Actor's construct reality based on their views, which depends on their position in the world they want to change or preserve (Costa, 2006). Thus the field rules shapes the habitus of an actor.

Further, Bourdieu states that the resources in a field are not evenly distributed among actors. Hence, there is a struggle among actors, which sparks up symbolic violence, especially when certain practices or ideas are taken-for-granted (Doxa). Due to the uneven distribution, a field could undergo some change or be preserved through reproduction based on field rules, habitus and capital accumulation (Bourdieu \& Wacquant, 1992; p.18). The study finds Bourdieu's theory to be very instrumental in interpreting recent bank failures in Ghana amidst the bank regulations.

\section{Research Design And Methodology}

The research methodology is qualitative because the researchers wanted some rich insights on the collapsed banks to make some analytic generalisations. A case study research design was also adopted. Cases of the nine failed Ghanaian banks namely; UT, Capital, The Beige Bank, The Construction Bank, Sovereign Bank, Unibank; The Royal bank; Heritage Bank and Premium Bank were considered.

The sample was selected using the purposive sampling technique. Due to the nature of the study only documents and materials that could help explain the failed Ghanaian banks were considered. The study drew largely on the reports and press releases of the Bank of Ghana (BoG), PriceWaterhouseCoopers, expert analysis from reliable online media sites such as thebftonline, myjoyonline, citifmonline, daily graphic, ghanaweb and other peerreviewed documents and newspapers.

The data was analysed using content analysis. Qualitative content analysis is defined as "a subjective interpretation of the content of text data through systematic classification process of coding and identifying themes or patterns" (Hsieh \& Shannon, 2005, p.1278; Bengtsson, 2016). There are two kinds of content analysis namely the manifest and latent content analysis. Specifically, latent analysis: examining the core/inherent meaning of the text (Berg, 2001), was utilized. This method of analysis makes inferences from the text. Thus, it seeks to discover and communicate the hidden meanings of the text. The authors conducted a content analysis on the narratives gathered on the recent bank failures in Ghana and other peer reviewed documents. The narratives were used because they are believed to reflect the purposes and intentions of human actors and as well help to understand their actions (Richardson, 1990). The authors observed the texts: words were the unit of analysis, and identified their implied meaning based on the context. Consequently, the data was thematically analyzed through the lens of the theories adopted. Thus, themes such as saints, demons, wizards and so on were generated.

\section{Findings}

\section{Brief Overview of Failed Banks}

The banks that were involved in the crisis were UT Bank, Capital Bank, UniBank, The Royal Bank, The Beige Bank, Sovereign Bank, The Construction Bank, Premium Bank and Heritage Bank. 
The narratives reveal the causes of the bank crisis to be non-performing loans, corrupt practices - financial engineering, inadequate capital, high inflation, fiscal account deficits, poor liquidity, high and volatile exchange rate development, governance challenges and weak financial sector supervision and regulation $(\mathrm{BoG}$, 2018). According to the report, CG structures were completely disregarded. For instance, there was some collusion among management responsibilities undermining credit and risk management policies (BoG, 2019). Prior, to the collapse, an asset quality review in 2016 showed a low value of assets in the banking sector. Also, it was realized the regulators fared poorly in supervising and exercising due diligence resulting in banks' regulatory breaches. Poor ethical behaviour of some bank actors negatively affected the banking system (Banahene, 2018).

It was noted that all the failed banks were locally owned. Therefore, the regulator would have to coach local banks so they could compete with their foreign counterparts.

\section{Ghanaian Banking Crises: Is it new or just a reproduction of social actions?}

Historical experiences shape the practices of actors. It is perceived that agents reproduce certain practices if the conditions under which the habitus was learned are the same (Costa, 2006).

The researchers observed the banking field and also applied Bourdieu's concept to answer the question of whether the crises were a reproduction of social actions. Historically, the Ghanaian banking field has experienced about five major bank crises. Antwi-Asare and Addison (2000, p.21) recount the reasons for the failures in 1970 and 1983.

"Severe inflation led to severe under-
capitalisation of banks... widespread
default on bank loans... devaluation of
currency....no clear quantified legal
definitions relating to financial sector
practices, insufficient legal penalties... and
the questionable supervisory capacity of the
BoG..."

Almost a decade after that crisis, the country experienced another crisis involving two foreign-owned banks: Bank of Commerce and Credit International and Meridien BIAO, and two locally-owned banks: Bank of Housing and Construction and the Cooperative Bank Ghana, in 1990 and 2000 respectively (Oxford Business Group, 2014). Liquidity problems, corrupt practices as well undercapitalisation underpinned their failures (Antwi-Asare \& Addison, 2000). The narratives on the failure of the local banks were expressed:

"BoG's decision to liquidate these banks followed persistent losses and the inability of banks to satisfy minimum capital requirement... fraudulent withdrawals and advances of huge sums of money worth 120 billion to A-life, a supermarket chain."

- Alesu-Dordzi (2019)

Again, the poor corporate governance mechanisms, ineffective supervision and some political interference were evident in the collapse of these banks. Also, the culprits were not sanctioned.

Despite these, the country witnessed a swarm of bank failures again sixteen years 
later hence the collapse of the nine banks under study. The recent failures are like shadows of the past. However, central to these crises has been the issue of poor ethics. Specifically, the BoG expressed it in this manner:

"...A number of legacy problems have plagued the banking sector including macroeconomic factors, corporate governance and risk management practices, related party transactions, regulatory non-compliance and poor supervision: questionable licensing processes and weak enforcement leading to a significant build-up of vulnerabilities in the sector".

- BoG (2018)

These observations concur with the findings of Laeven and Levine (2009), IMF (2011), Brown and Dinç (2005), Diamond and Rajan (2005), and Bernburg (2016).

The narratives connote that there has been some reproduction of past events or practices (poor CG, regulatory framework and supervision as well as inadequate risk management). This was bemoaned by the governor - Dr. Addison at an Annual (2017) dinner of the Chartered Institute of Bankers (Ghana).

"...In recounting history, I am seeking to draw attention to the adage that history repeats itself. Despite the improved regulatory environment and supervisory frameworks, we have witnessed the resolution of two banks this year".

However, there have been some new dynamics. For instance, creative accounting was adopted since most of them inflated their loans and advances to customers (assets) and understated liabilities such as customer deposits.

That notwithstanding, some themes seem not to have changed - poor CG practices, poor regulatory and supervision and poor credit management. Also, the BoG has over the years remedied such issues extensively with bank recapitalization; which dates back to the 1970s, without any punitive measures for deviants (Afolabi, 2017). Hence, it could be concluded that largely the Ghanaian banking crises are a reproduction of old social actions despite the new field rules enacted for actors in the field. Thus, these field rules have not yet shaped their habitus. Besides, the doxic nature is strong, especially among the indigenous banks hence leading to a reproduction of actions befitting bank crisis.

\section{Did the Structure of banks in Ghana Account for the failures?}

The structure of banks could be explained from the perspective of capital, field positions and field rules. Thus the systems and processes of banks qualify as structures.

Ghana's banking sector is made up of both foreign and local banks. The number of local banks and foreign banks as at December 2016 was sixteen and seventeen respectively. However as at the end of 2017, there was a tie: an equal number of foreign and local entrants, so the total number of banks was thirty-four. To ensure customer security, the Bank of Ghana increased the minimum capital requirement in 2017. This increment was a pain in the neck for most of the local banks compared to their foreign counterparts. PricewaterhouseCoopers and Association of Bankers (2017, p.17) revealed that: 
"The local banks appear quite concerned about the impact of the risk-based capital framework on their capital requirement. Even under the existing framework, some local banks may require capital injection".

Consequently, the number of local banks declined to nine whereas that of the foreign banks fell to fourteen in 2019. In terms of branch ownership, the local banks had about $65 \%$ of the total num-ber of bank branches in 2017. That notwithstanding, the bank with the highest market share: share of industry deposits, for the years 2016 and 2017 was a foreign bank Ecobank Ghana, except for 2018 which was GCB bank. Thus, the foreign banks dominate the banking industry in terms of number and assets although the local banks have many branches. The dominance of foreign banks in the Ghanaian banking sector concurs with Antwi-Asare and Addison (2000).

Specifically, the habitus; transposable values, from their parent organisations might have influenced their banking practices hence their dominance in the sector. Thus, the dominance of foreign controlled banks in the Ghanaian banking field indicates their high levels of economic capital - a higher proportion of banks' total assets, and cultural capital experience and exposure. A description of this is stated below;

“... multinational banks appear to be less concerned about regulatory capital as well as systems and data and people and skills. These banks believe they already have the systems in place and could easily reach out to their network for assistance".

- PricewaterhouseCoopers and

Association of Bankers (2017, p.17)
Unlike these foreign banks, most of the local banks lacked the appropriate structures. Banks are supposed to be managed by people with requisite knowledge, experience and possess moral integrity (BoG, 2018). This wasn't the case in most of the local banks. For instance, Capital bank: one of the failed banks, board chairman lacked the appropriate cultural capital needed to participate in the field of banking. He affirmed this by stating that:

"I didn't have a banking training, but I am a chairman of a bank..... But you know money is so easy to understand.... I was horrible with mathematics and still horrible with mathematics but really in Finance you don't need serious mathematics, its just addition and subtraction".

- www.ghanaweb.com (2018)

The observation of foreign banks being dominant and having appropriate structures should have brought some changes in the actions of participants in the field. However, failure on the part of the key field actor - the regulator might have accounted for these failures. This is because the central issue for the collapsed local banks was governance - starting with the regulator - BoG governors and supervisors, who are the principal actors in the banking field. The poor governance trickled down to the executives of the failed banks.

"...governance challenges in the banking system spilled over and significantly weakened financial sector supervision and regulation, while CG structures were completely disregarded bence affecting the risk systems"

- BoG (2018) 
Over the period, the regulations of BoG have been taken for granted (doxa) by most of the actors, especially the local ones resulting in symbolic violence: noncompliance to the field rules. This is asserted because despite the enactment of Act 930 in 2016, these local banks still acted contrary to the stipulations in the Act, which was expected to structure their operations. Besides, the country is known for regulations but not necessarily its enforcement.

"Our inability to respect the laws as a nation throws us back into the animals' kingdom... I believe that institutions should lead the way by enforcing regulations governing their sector....".

- Anokye (2019)

This idea could have been internalized by the actors of the failed local banks. Also, it could explain why a chairman of the collapsed banks; though being of high office failed to ensure its bank's activities complied with the Act. Further, the key actors - BoG as well as the Securities and Ex-change Commission (SEC) failed in their governance since they did not sanction banks that failed to submit their annual reports and undertake due diligence. Again, these observations could give credence to Boubakri et al. (2017) on culture playing a role in bank performance.

\section{Actors}

Ayee (2000) concepts for policy failures or success is applied to theorize the actors involved in the bank failures. In addition, the study introduces the concept of pagans and prophets. The banking field has lots of actors and they will be discussed in the subsequent sections.

\section{Saints}

According to Ayee (2000), saints are committed officials and leaders who are willing to shoulder the risk of formulating and implementing policies no matter how unpleasant they may be to the populace.

\section{Current leadership of the Bank of Ghana}

Based on this conceptualization, the researchers deduced that the current governor: as the saint. Under his leadership, he has worked closely with other officials to ensure that non-compliant or deviant banks are eliminated regardless of the cost and chastisement from the populace and some government and top officials. He bemoaned that:

"We inherited a financial system which was under a considerable state of distress, with banks that were not meeting capital adequacy requirement... with high nonperforming loans... were insolvent and illiquid, others were solvent butilliquid"

$$
\text { - BoG (2018, p.4) }
$$

The governor and his team had to interact with stakeholders on how to address the problems that had bedeviled the sector.

"...We took decisive actions underpinned by a strengthened legal framework... we closed a total of seven insolvent banks and protected depositors' claims...to ensure the rest of the banking sector did not sufferfrom contagion"

$$
\text { - BoG (2018, p.5) }
$$

He did not pursue this agenda without counting the cost. The decision involved a huge price and the likelihood of being badmouthed by the populace and some officials who were responsible for the crisis. He asserted: 
"...the failure of the collapsed banks came at a cost to the Ghanaian taxpayer, staff to an extent, and shook confidence in the financial sector."

$$
\text { - BoG (2018, p.5) }
$$

Thus, the quest to sanitize the banking sector must have been a challenging feat that demanded some resilience from the policymakers. Since, one's actions are easy to be misconstrued. He concurred with that observation.

“... we have taken very difficult decisions...rather unpleasant but needful decisions to ensure stability in the finance system....."

- Myjoyonline (2018)

Besides Ayee (2000) claimed that saints are public officials or leaders who make sacrifices no matter how tough and unpopular their decisions may be, to bring some transformation and sanctity. There are countless evidences supporting the fact that the current leadership of BoG have taken tough or unpopular decisions over the past two years in their quest to clean up the banking sector (BoG, Jan 2019).

The actions of the current leadership of BoG could be explained by Bourdieu's concept of habitus. This is because the governor is known to have some knowledge and experience on bank failures and bank reforms (see Antwi-Asare \& Addison, 2000). Hence those dispositions shaped his actions and decisions to put in mechanisms that could aid banks in the country to compete or interact with other banks even at the global level.

\section{Government}

Also, per our observation, the government could be considered as a saint in addressing the bank failures. This was inferred from the actions of the government on this matter and validated by the vice president:

"The government will support any policy/initiative aimed at consolidating gains made so far in the banking sector"

- The Ghanaian Banker (2019, p.11)

This assertion was further affirmed by the governor:

"...the bank of Ghana has enjoyed considerable political support enabling it to be effective to implement these rather difficult measures to comprehensively reform the banking and specialized deposit-taking institutions sectors of the finance system"

$$
\text { - BoG (2019, p.3) }
$$

\section{Demons}

Demons are used to symbolize public officials and individuals who engage in corrupt practices. They seek the failure of policies. In this paper, actors who contributed by way of collusion and abuse of power are considered as demons.

\section{Some governors and officials from the Supervision}

\section{Department of the Bank of Ghana}

We theorized the immediate past deputy governors and officials from the supervision department of the BoG particularly during 2014 and 2016 as one of the demons of current Ghana's bank crisis. This is because despite, the power that was wielded in them by the current Act 930 and Act 918 enacted in 2016, these officials failed to perform their duties diligently. Besides, poor supervision and 
law enforcement by the regulatory agency has been one of the causes for the failures. The actions of the past BoG governor and officials validate this observation:

"Our predecessors continued to provide liquidity support to these weak. failing banks without addressing the underlying problems that led to illiquidity and insolvency of these institutions".

$$
\text { BoG (2018, p.5) }
$$

Further, it was found that the previous leadership took for granted the resources; regulations, from which their position and power were derived from. Their social conditioning could explain their practices. As though the failure of the leadership to perform its fiduciary duties wasn't enough, they equally ignored expert assistance. This is buttressed by the point that -

"There is no evidence to show how the previous management took steps to mitigate the risk of the ultimate failure of these institutions as required to do under Act 930. The then management failed to implement actions suggested by the IMF that would have halted the collapse of the multitude of financial institutions. Instead, massive amounts of liquidity support were granted insolvent banks and also through other banks as conduits and taking no steps to ensure that such support was used for the benefit of providing liquidity to depositors".

BoG (2019, p.1)

Again, an action of the immediate past deputy governor fits the theorization by Ayee considered as a demon. Ayee (2000, p.44) asserted that demons could be officials who perceive a policy may threaten their power, position and competence.
Besides, one of the questions lingering on the minds of people was where actors of the regulatory bodies were whilst some banks made a mess of themselves. This could be the reason he tried to justify his actions in the past and probably because he feels his competence is being threatened by stating:

...there were well-intentioned reasons some of the collapsed banks were issued licences... Key among these was the thinking at the time to encourage indigenous banks to also feature in the banking landscape...."

- Kunateh (2019)

He also moaned that

"Every action that was undertaken was guided by its regulations.... and we did our best to ensure that the right thing was done". - Myjoyonline (2019)

Deducing from the discourses above, it could be that the past executives of BoG feel threatened/uncomfortable that their current colleagues will be praised for making and implementing difficult but necessary policies whereas they couldn't do much to safeguard the situation. His actions are described below:

It is instructive to note that $A J . .$. when the decision was taken to revoke the licenses of UT Bank and Capital Bank and had every opportunity to propose any other strategy for addressing the insolvency of the said banks if he felt there was a better and more effective strategy... what he fails to admit is the fact that the swift and decisive action taken by the Addison-led management team provided relief for other segments of the financial system...."

- BoG (2019) 
Thus, AJ is theorized as a demon: based on Ayee (2000) conceptualization, because of his negligence and lack of commitment to assist the policy interventions of the current administration as well as not doing due diligence during his tenure of office which amounted to the failed banks. However, considering his position as a past policy maker he could also be considered as a fallen saint since he failed to live up to the expectation of his office.

\section{Directors, Bank shareholders and relatedparties}

These actors colluded with management and engaged in malpractices. All attempts by the policymakers to rectify their misdoings came to naught.

Monies granted some of the failed banks were spent lavishly by the directors instead of investing them properly to arrest the negative situations of their banks. Almost all of these banks had their directors, shareholders and connected parties conniving in some fraudulent or improper activities that were harmful to the going concern of the banks. This was depicted clearly in the case of UT Bank, Capital Bank, and UniBank. These three banks' directors and shareholders in connivance with bank management shared BoG liquidity supports amongst themselves and connected people. For instance:

"UniBank's shareholders and related parties have admitted to acquiring several real estate properties in their own names using the funds they took from the bank."

$$
\text { - BoG (2018, p.7) }
$$

Some of these actors disregarded the regulatory body because of the power they wielded in society as well as their political connections. As a result, some still managed to get some support from BoG despite their short-comings. Evidence shows that:

"... a key shareholder of one of the failed banks managed to obtain liquidity support from the Bank of Ghana using third party banks as its agents"

- BoG (2018)

Most of these share-holders sought to outsmart the banking system of operations. For instance, Heritage Bank, The Construction Bank, The Beige Bank and Sovereign Bank had their shareholders contribute nothing in terms of capital. Evidence to validate that are presented below:

“...Sovereign bank's initial capital contributed by its shareholders was funded from transfers from Capital Bank which was presented to Bank of Ghana as investments on behalf of the bank... Promoters of Sovereign bank admitted they did not pay for the shares they acquired in the bank" "Construt

"Construction Bank's capital was loans from NIB Bank and UniBank".

$$
\text { - BoG (2018, p.9) }
$$

These capital contributions were however non-existent/inaccessible. The deceptive means some used in acquiring their licences even attest to the fact that they can be classified as demons of the banking system.

\section{Management of Banks}

It is mindboggling to read that one of the reasons for the bank collapse was creative accounting and financial engineering practices considering all that the accounting profession has undergone after the global 
crisis. The financial statements of most of the banks suggested they had satisfied the conditions for going concern. However, an inquiry by KPMG in undertaking their receivership assignment revealed otherwise:

"The balance sheets of three of the banks showed very high overstatements of asset values. Before the adjustments, Sovereign, The Beige and The Royal Bank recorded totals of about 462 million, 2.428 billion and 1.004 billion Cedis respectively as against 191 million, 499 million and 376 million Cedis reported after adjustment and reclassification have been made".

Amlanu (2019)

Despite the ethical training accountants receive, it is quite worrisome to see these actions. Is it a matter of changing identities because they find themselves in a banking environment and as such forget their identity and act as bankers?

Also, the role of the bank managers in these failures cannot be understated. Due to the poor CG structures, most of the managers acted in their interest as against the welfare of the banks. The inability of bank management to challenge poor CG practices and whistle blow fraudulent bank practices accounted for the bank crises.

\section{Bad Customers}

Customers of banks who defaulted on their loans could also be classified as demons. One of the reasons for the bank failures was high non-performing loans connoting the defaulters of loans and advances were high. The contribution of customers to bank crisis is described:
"People hardly talk about the contribution of customers in bank collapses...it is common to see exuberant customers flocking a new bank, pretending to be first-time bankers ...they divert funds taken from their previous bankers into these new banks. Some naive bankers swallow this bait and without associated credit risk analysis recommend big facilities to these fraudsters. These funds are quickly sent back to where they belong, leaving a vacuum in the new banks"

Quarcoopome (2018)

Therefore, policy formulators and implementers must not be oblivious of the impact of bad customers on the well-being of banks.

\section{Wizards}

Wizards are perceived as policy analysts with available and reliable information which could assist policymakers in formulating and evaluating policies. Whilst appropriate wizards aid policy success, inappropriate wizards cause policy failures. Empirically, Pricewaterhouse Coopers Country Senior Partner - V. A. and his research team could be classified as appropriate wizards. Pricewaterhouse Coopers and Association of Bankers have consistently been under-taking banking surveys in Ghana to help identify the problems and challenges in the industry and the likely solutions to be applied. Together, V. A., and E. N. of PwC and N. A. D. of KPMG have assisted the BoG with reliable information in dealing with the failed banks.

"The Bank of Ghana appointed N. A. D of KPMG as official administrator for UniBank to help ascertain the true financial condition of the bank, protect depositors 
fund and explore bow the bank could be returned to viability within a period of no laterthan six months"

$$
\text { BoG (2018, p.5) }
$$

However, the external auditors of the failed banks as well as the officials of GSE and SEC could be likened to inappropriate wizards. This is because, despite the auditors' access to the documents and details of their clients, they constructed a reality that was contrary to their clients' actual performance. Thus they failed as watchdogs for the users of the accounting information of the dissolved banks. And this concurs with the Sikka (2009) observation.

Also, SEC and GSE equally failed in their tasks. SEC de-listed UT Bank after BoG had revoked the bank's license despite UT bank's failure to publish its financial statements twice in a row.

\section{Pagans}

From the data, some actors involved in the banks' failures could be classified as pagans. Pagans here represent individuals who have doubt and are self-indulgent. There have been a number of discourses suggesting the collapse of the banks under study was staged. Some of the individuals are still in doubt despite some facts been clarified. Specifically, a CEO's of one collapsed bank articulated that he finds the dissolution of some of the banks particularly Heritage Bank to be politically motivated:

"I find that extremely, extremely unfair, $\mathrm{Mr}$. K. A. asserted adding: Maybe I don't have all the facts, but from where I stand, I find it really unfortunate".

- www.ghanaweb.com (2019)
A. K. further asserted that the collapse of the bank he managed has resulted in severe business challenges for other companies under the holding group of which he is the president. He emphasized that the actions of the BoG have defamed him. Another CEO of a failed bank, A. E., also claimed that his refusal to hand over the bank he was managing to one of the top current political officials is what led to the collapse of the bank despite facts on how he mismanaged the funds of the bank.

\section{Prophets}

Again, some actors predicted the state of the country's banking system before the collapse of the banks in question. The study found two of them to be researchers: academia and consultancy.

The IMF in 2011 based on its assessment of the country's financial statement revealed that the sector was plagued by governmental influence, poor risk management, and high NPLs and predicted a likely bank crisis. Again, Aboagye and Ahenkora (2018) predicted the failure of three banks.

Also, one of the experts who happen to be the current vice president of Ghana predicted in 2016 the closure of about eight banks. He based his predictions on the non-performing loans and the asset quality review in 2015. Akrong (2018) indicated per his analysis the collapse of nine banks.

\section{Conclusion}

It was observed that that poor corporate governance systems from both the banks' and regulator perspectives amounted to the recent bank failures in Ghana. Specifically, the presence of improper 
structures and opportunistic actors who took advantage of the gaps in the banking system resulted in the collapse of the nine banks. The study set out to find the causes of Ghana's bank crisis from both the structural and agency perspectives. It can be concluded that the recent bank crisis in Ghana which resulted in the collapse of nine banks was largely a reproduction of past banking practices and poor structures.

In addition, it could be asserted that the presence of fallen saints; hungry and deceptive demons; inappropriate wizards; praise-seeking pagans, and lack of attention to prophets were responsible for the bank crisis or failures in Ghana. However,

\section{REFERENCES}

Aboagye, A. Q., \& Ahenkora, E. (2018). Stress Testing Exposure of Banks to Sectors of the Ghanaian Economy. Journal of African Business, 19(1), 27-38.

Afolabi, J.J. (2017, May 16). Recapitalisation-A means of transforming banking sector. Graphic Online, pp.1. https://www.graphic.com.gh / features/features/recapitalisation-ameans-of-transforming-bankingsector.html.

Akrong, E. (2018, April 2). 32 banks fail to comply with financial statement publication rules. Citifmonline. http://citifmonline.com/ 2018/04/32-banks-fail-comply-financialstatement-publication-rules-article/

Alagidede, P., Baah-Boateng, W., \& NketiahAmponsah, E. (2013). The Ghanaian Economy: An Overview. Ghanaian Journal of Economics, 1(1), 4-34.

Alesu-Dordzi (2019, April 1). Ghana's 2000 Banks Collapse (Part 1). Ghana Law Hub. https://ghanalawhub.com/ghanas-2000banks-collapse-part-1/

Amlanu, J. W. (2019, January 28). Recoveries from the possibility of a contagion was minimized by the timely intervention of some saints and appropriate wizards.

The study contributes to research by its application of Bourdieu's Social Theory of Practice (1977), Ayee's (2000) concepts of policy failures and some religious concepts to explain Ghana's bank failures. The researchers hope that policymakers would consider all these actors when formulating and implementing policies.

Future studies could use different research methods to gain deep insights into why some actors; especially auditors, failed to predict and communicate the failure of these banks.

liquidated banks unlikely. Goldstreet Business. https://goldstreetbusiness.com/2019/busi ness/recoveries-from-liquidated-banksunlikely/

Anokye, K. (2019, September 6). Financial sector cleanup: the good, bad and ugly. GhanaWeb. https://www.ghanaweb.com/GhanaHome Page/features/Financial-sector-cleanupThe-good-bad-and-ugly-778943

Antwi-Asare, T. O., \& Addison, E. K. Y. (2000). Financial Sector Reforms and Bank Performance in Ghana. London: Overseas Development Institute.

Arif, A., \& Nauman, A. (2012). Liquidity Risk and Performance of Banking System, Journal of Financial Regulation and Compliance, 20(2), 182-195.

Ayee, J. R. (2000). Saints, Wizards, Demons, and Systems: Explaining the Success or Failure of Public Policies and Programmes. Ghana Universities Press, Accra

Banahene, K. O. (2018). Ghana banking system failure: the need for restoration of public trust and confidence. International 
Journal of Business and Social Research, 8(10), 15.

Bank of Ghana (2018). Banking Sector Report. https: / /www.bog.gov.gh/wp-content /uploads/2019/08/Banking_Sector_Repo rt_January_2018-1.pdf

Bank of Ghana (2018). Banking Sector Report. https://www.bog.gov.gh/wp-content /uploads/2019/08/Banking_Sector_Repo rt_May_2018-1.pdf

Bank of Ghana (2018). Banking Sector Report. https://www.bog.gov.gh/wp-content /uploads/2019/08/Banking_Sector_Repo rt_July_2018-1.pdf

Bank of Ghana (2018, August). Government establishes new indigenous bank; Bank of Ghana revokes licences of five banks and appoints receiver in respect of their assets and liabilities [Press release]. https://www.bog.gov.gh/wpcontent/uploads/2019/07/PRESSRELEASE-Grand-Final-August-2018.pdf

Bank of Ghana (2018, December). Annual Dinner of Chartered Institute of Bankers Address by Dr. Ernest Addision, Governor Bank of Ghana. https://www.bis.org/review /r181220g.pdf

Bank of Ghana (2018, March 28). Bank of Ghana appoints official administrator for UniBank Ltd. [Press release]. https:// media.peacefmonline.com/docs/201803/ 582758611_790008.pdf

Bank of Ghana (2018, September 19). Speech delivered by second deputy governor - Mrs. Elsie A. Awadzi at the Ghana Bar Association Annual Conference. Ghana Talks Business. https://ghanatalksbusiness .com/2018/09/speech-delivered-seconddeputy-governor-mrs-elsie-awadzi-ghanabar-association-annual-conference/

Bank of Ghana (2019). Banking Sector Report. https://www.bog.gov.gh/wp-content/ uploads/2019/08/Banking_Sector_Report _May_2019-1.pdf

Bank of Ghana (2019). Banking Sector Report. https://www.bog.gov.gh/wp-content/ uploads/2019/08/Banking_Sector_Report January_2019-1.pdf

Bank of Ghana (2019). Banking Sector Report. https://www.bog.gov.gh/wp-content/
uploads/2019/08/Banking_Sector_Report March_2019-1.pdf

Bank of Ghana (2019). Banking Sector Report. https://www.bog.gov.gh/wp-content/ uploads/2019/08/Banking_Sector_Report _July_2019-1.pdf

Bank of Ghana (2019). State of the financial sector. https://www.bog.gov.gh/wpcontent/uploads/2019/07/State-of-theBanking-System.pdf

Becker, H. S., \& Horowitz, I. L. (1972). Radical Politics and Sociological Research: Observations on Methodology and Ideology, American Journal of Sociology, 78(1), 48-66.

Bengtsson, M. (2016). How to Plan and Perform a Qualitative Study Using Content Analysis. NursingPlus Open, 2, 8-14.

Berg, B. L. (2001). An Introduction to Content Analysis. Qualitative Research Methods for the Social Sciences, 7, 238-267.

Bernburg, J. G. (2016). Economic Crisis and Mass Protest: The Pots and Pans Revolution in Iceland. Routledge.

Boubakri, N., Mirzaei, A., \& Samet, A. (2017). National Culture and Bank Performance: Evidence from the Recent Financial Crisis, Journal of Financial Stability, 29, 36-56.

Bourdieu, P. (1977) Outline of a Theory of Practice, [translated by Richard Nice], New York, Cambridge University Press.

Bourdieu, P. (1986) 'Forms of Capital' http://www.marxists.org/reference/subje ct/philosophy/works/fr/bourdieu-formscapital.htm] accessed Jan-12

Bourdieu, P., Wacquant, L. (1992) An Introduction to Reflexive Sociology, Cambridge, Polity

Brown, C. O., \& Dinc, I. S. (2005). The Politics of Bank Failures: Evidence from Emerging Markets. The Quarterly Journal of Economics, 120(4), 1413-1444.

Calomiris, C. W. (2008). Banking crises. The New Palgrave Dictionary of Economics, Volume 1-8, 348-352.

Carbo-Valverde, S. (2017). The Impact on Digitalization on Banking and Financial Stability. Journal of Financial Management, Markets and Institutions, (1), 133-140.

Čihák, M., \& Schaeck, K. (2010). How well do 
Aggregate Prudential Ratios Identify Banking System Problems? Journal of Financial Stability, 6(3), 130-144.

Collapse of Heritage Bank "extremely unfair"- Amoabeng (2019, September 26). GhanaWeb. https://www.ghanaweb.com /GhanaHomePage/business/Collapse-ofHeritage-Bank-extremely-unfairAmoabeng-784002

Collapsing troubled banks was painful decision - Dr. Ernest Addison (2018, August 6). Myjoyonline. https://www.myjoyonline. $\mathrm{com} /$ business/collapsing-troubled-bankswas-painful-decision-dr-ernest-addison/

Costa, R. L. (2006). The Logic of Practices in Pierre Bourdieu, Current Sociology, 54(6), 873-895.

Cull, R., \& Soledad Martinez Peria, M. (2010). Foreign bank participation in developing countries: what do we know about the drivers and consequences of thisphenomenon? The World Bank.

Demirgüç-Kunt, A., \& Detragiache, E. (1998). The Determinants of Banking Crises in Developing and Developed Countries, Staff Papers, 45(1), 81-109.

DeYoung, R., \& Torna, G. (2013). Nontraditional Banking Activities and Bank Failures during the Financial Crisis. Journal of Financial Intermediation, 22(3), 397-421.

Diamond, D. W., \& Rajan, R. G. (2005). Liquidity Shortages and Banking Crises, The Journal of Finance, 60(2), 615-647.

Dzawu, M.M. (2019, September 10). Ghana Strengthens Capacity to Avoid Repeat of Banking Cleanup. Bloomberg, pp.1. https://www. bloomberg.com/news/articles/2019-0910 /ghana-strengthens-capacity-to-avoidrepeat-of-banking-cleanup.

Falasca, K. (2014). Framing the Financial Crisis: An Unexpected Interaction between the Government and the Press. Observatorio (OBS $\left.{ }^{*}\right), 8(1), 01-21$.

Flashback: Banking is not that tough; it's just common sense - Otabil (2018, August 24). GhanaWeb. https://www.ghanaweb.com /GhanaHomePage/NewsArchive/Flashba ck-Banking-is-not-that-tough-it-s-justcommonsense-Otabil-679070?channel $=\mathrm{D} 1 \&$ channel $=\mathrm{D} 1 \&$ channel=D1\&channe
$\mathrm{l}=\mathrm{D} 1$

Garcia, G. G., \& Nieto, M. J. (2005). Banking Crisis Management in the European Union: Multiple Regulators and Resolution Authorities, Journal of Banking Regulation, 6(3), 206226.

Ghosh, A. (2016). How does Banking Sector Globalization affect Banking Crisis? Journal of Financial Stability, 25, 70-82.

Guerrera, F., \& Thal-Larsen, P. (2008). Gone by the Board: Why the Directors of Big Banks Failed to spot Credit Risks, Financial Times, 26.

Hernando, M. G., Pautz, H., \& Stone, D. (2018). Think Tanks in 'hard times'-the Global Financial Crisis and Economic Advice, Policy and Society, 37(2), 125-139.

Hill, C. A. (2009). Who Were the Villains in the Subprime Crisis, and why it Matters, EntrepreneurialBus. LJ, 4, 323.

Holm, C., \& Zaman, M. (2012). Regulating Audit Quality: Restoring Trust and Legitimacy, Accounting forum, 36(1), pp. 51-61.

Honohan, P., \& Klingebiel, D. (2003). The Fiscal Cost Implications of an Accommodating Approach to Banking Crises, Journal of Banking \& Finance, 27(8), 1539-1560.

Kunateh, M.A. (2019, August 24). Former Deputy Governor of BoG punches more holes in financial sector cleanup. African Eye Report. https://africaneyereport.com/formerdeputy-governor-of-bog-punches-moreholes-in-financial-sector-cleanup/

Laeven, L. (2011). Banking Crises: A Review. Annual. Review, Financial. Economics, 3(1), 17-40.

Laeven, L., \& Levine, R. (2009). Bank Governance, Regulation and Risk Taking, Journal of financialeconomics, 93(2), 259-275.

Laeven, L., \& Valencia, F. (2013). Systemic Banking Crises Database, IMF Economic Review, 61(2), 225-270.

Laeven, M. L., \& Valencia, F. (2010). Resolu-tion of Banking Crises: The Good, the Bad, and the Ugly (No. 10-146), International Monetary Fund.

Lietaer, B., Ulanowicz, R., \& Goerner, S. (2009). Options for Managing a Systemic Bank Crisis. SAPI EN. S. Surveys and 
Perspectives Integrating Environment and Society, (2.1).

Magnan, M., \& Markarian, G. (2011). Accounting, Governance and the Crisis: is Risk the Missing Link? European Accounting Review, 20(2), 215-231.

Minford, P. (2010). The Banking Crisis: a Rational Interpretation, Political Studies Review, 8(1), 40-54.

Muranda, Z. (2006). Financial Distress and Corporate Governance in Zimbabwean Banks. Corporate Governance International Journal of Business in Society, 6(5), 643-654.

Neate, R. (2012). Financial Crisis: 25 people at the Heart of the Meltdown-where are they now. The Guardian, 6.

PricewaterhouseCoopers and Association of Bankers (2016). 2016 Ghana Banking Survey: How to win in an era of mobile money. https:/ / www.pwc.com/gh/en/assets/pdf/2016banking-survey-report.pdf

PricewaterhouseCoopers and Association of Bankers (2017). 2017 Ghana Banking Survey. Risk-based minimum regulatory capital regime: what it means for banks in Ghana. https: //www.pwc.com/gh/en/assets/pdf/2017 -banking-survey-report.pdf

PricewaterhouseCoopers and Association of Bankers (2019). Banking reforms so far: topmost issues on the minds of bank CEOs. https:// www.pwc.com/gh/en/assets/pdf/ghanabanking-survey-2019.pdf

Quarcoopome, A. (2018). The day History Repeated itself? the Sad Reminders, even after 17 years! https://thebftonline.com/archive/ more.php?ID $=25940$
Richardson, Laurel (1990). Narrative and sociology. Journal of Contemporary Ethnography, 19, 116-135.

Sanoran, K. L. (2018). Auditors' Going Concern Reporting Accuracy during and after the Global Financial Crisis, Journal of Contemporary Accounting \& Economics, 14(2), 164-178.

Sikka, P. (2009). Financial Crisis and the Silence of the Auditors, Accounting, Organizations and Society, 34(6-7), 868-873.

Sikka, P., Filling, S., \& Liew, P. (2009). The Audit Crunch: reforming auditing, Managerial Auditing Journal, 24(2), 135-155.

The Ghanaian Banker (2019, April 12). Keynote Address - Building confidence in the banking industry in Ghana, His Excellency Dr. Mahamudu Bawumia. Journal of Chartered Institute of Bankers, 1. https://www.cibgh.org/download/file/fid $/ 954$

Vyas, M., \& Singh, S. (2011). Risk Management in Banking Sector. BV TMR Management Edge, 4(1).

Wallgren, E., \& Lindé, A. (2012). The Effects of Organizational Structure and Rules on Banks Risk Management: A Comparative Case Study of Three Major Banks in Sweden.

We were going to undertake banking sector cleanup at a less cost - Former Dep Governor (2019, August 21). Myjoyonline. https://www.myjoyonline.com/business/b anking/we-were-going-to-undertakebanking-sector-cleanup-at-a-less-cost-aeformer-dep-governor/ 